\title{
THE EFFECT OF MANAGERIAL OWNERSHIP, PROFITABILITY, SOLVABILITY AND COMPANY SIZES ON PROFIT MANAGEMENT IN PROPERTY AND REAL ESTATE COMPANIES WHICH ARE IN THE INDONESIAN STOCK EXCHANGE PERIOD $2013-2017$
}

\author{
Rosa Dwi Agsari \\ Universitas Buddhi Dharma
}

\begin{abstract}
This study was conducted to examine the effect of Managerial Ownership, Profitability, Solvency and Company Size variables on Profit Management partially on property and real estate companies listed on the Indonesia Stock Exchange in the period 2013-2017. In addition, to examine the feasibility of a regression model of the influence of variable ownership variables Managerial, Profitability, Solvency and Company Size Management simultaneously on property and real estate companies listed on the Indonesia Stock Exchange in the period 2013-2017. This research was conducted on property and real estate companies on the Indonesia Stock Exchange for the period 2013-2017. The determination of the sample in this study uses a nonprobability sampling method with a purposive sampling technique in order to obtain a total sample of 8 companies and a total of 40 observations. The data in this study were analyzed using panel data analysis techniques.

The results showed that Managerial Ownership, Solvency and Company Size had no effect on Profit Management. Another variable in this study is that profitability has a positive and significant effect on earnings management. Simultaneously Managerial Ownership, Profitability, Solvency and Company Size Towards Profit Management. The predictive ability of the four variables on Profit Management is $22.84 \%$ as shown by the amount of Adjusted R-squared of 0.2284 while the remaining $77.16 \%$ is influenced by other factors not included in the research model.
\end{abstract}

Keywords: Earning Management, Managerial Ownership, Profitability, Solvency, Firm Size. 


\section{PRELIMINARY}

One important source of information aside from external parties in assessing financial performance is financial statements. Financial statements are one of the most important information for investors to assess the performance of companies that go public. In PSAK No. 1 of 2017 regulates the standardization of the presentation of financial statements, the structure of financial statements and the requirements for financial statements in order to achieve general objectives in making financial statements (general purpose financial statements), hereinafter referred to as financial statements. In a complete financial statement usually includes a balance sheet, income statement, cash flow statement, equity statement, notes to the financial statements and other reports as well as explanatory material that is an integral part of the financial statements (PSAK No. 1 of 2017).

Earnings management occurs because of agency conflict, which arises because of the separation between company owners and company managers. With this separation, the owner of the company gives authority to the manager over the course of the company, such as managing funds and making company decisions on behalf of the owner. This situation makes managers tend to be more superior in controlling information compared to other parties. This information gap between managers and other parties is called information asymmetry (Sulistyanto, 2014: 21).

Earnings management actions have led to several widely known cases of accounting reporting scandals, including Enron, Global Crossing, Kmart, WorldCom, Williams Cos., And Xerox. Some cases also occur in Indonesia, such as PT. Kimia Farma Tbk, PT. Agis and PT. Infracom Innovation (INVS). At PT. Kimia Farma Tbk, the company is estimated to make a net profit mark up in the 2001 financial statements. In the report, Kimia Farma said it managed to get a profit of Rp 132 billion. However, the reported earnings are in fact different. This pharmaceutical company in 2001 only made a profit of Rp 99 billion. (Source: Tempo.co)

Profitability ratios are ratios to assess a company's ability to seek profits. According to Herdian (2015) profitability is an indicator of performance by management in managing company wealth as indicated by the profits generated. This ratio also provides a measure of the effectiveness of a company's management. This is shown by the profits generated from sales and investment income. This ratio measures net profit after tax with own capital (cashmere, 2012: 204).

Research conducted by Selviani (2017) shows the results that profitability has a positive effect on earnings management. The positive meaning is that the higher the profitability, the more profit management increases, and conversely the lower the profitability, the lower the earnings management. This happens to companies companies that are experiencing increased profits. In contrast to research conducted by Fatmasari (2016) that profitability has no effect on earnings management.

According to Kasmir (2012: 151) the solvency ratio or leverage ratio is a ratio used to measure the extent to which a company's assets are financed with debt. This means how much debt burden borne by the company compared to its assets. Debt ratio is a debt ratio that is used to measure the ratio between total debt and total assets (Kasmir, 2012: 156).

If seen from several previous studies, there are differences in research results related to the effect of Solvency (leverage) on earnings management. In Agustia's (2013) research, 
the results show that leverage has a significant positive effect on earnings management. Leverage has a relationship with earnings management practices, investors will see the company's smallest leverage ratio, because the smaller the company's leverage ratio or the smaller the capital financed by debt, the company has a small risk as well, and vice versa. Whereas in Selviani's research (2017) it shows that leverage has no effect on earnings management.

\section{LITERATURE REVIEW}

\section{Agency Theory}

The development of corporate governance departs from agency theory developed by Jensen and Meckling in 1976 (Chartered Accountant Module, IAI (2015: 78). The theory is based on the contractual relationship between the principal and agent. Principals are parties who have resources and mandates the agent to act on behalf of the principal, while the agent is the party mandated by the principal to manage the resources.The agent has the responsibility to account for what has been mandated by the principal and has decision making authority that will affect the welfare of the principal.

With a high level of information asymmetry the agent's actions cannot be seen / observed properly so that the agent will tend to take actions that benefit him and harm the principal. This information gap is what drives agents to behave opportunistically in disclosing important information about the company. The greater the information asymmetry, the greater the impetus for agents to behave opportunistically (Chartered Accountant Module, IAI (2015: 78).

\section{Definition of Earnings Management}

According to Sulistyanto (2014: 6) earnings management is generally defined as an effort by company managers to intervene or influence information in financial statements with the aim of tricking stakeholders who want to know the performance and condition of the company.

The issue of earnings management is not new in the practice of financial statements. This is caused by the lack of company targets than predicted by the market. Pressure to make profit management performs earnings management by influencing earnings numbers which results in a decrease in the quality of the company's financial statements (Widarto, 2004) in Aji (2014). Earnings management is one of the factors that can reduce the credibility of financial statements and can cause bias so that it can interfere with the users of the financial statements of the figures presented.

\section{Good Corporate Governance}

Corporate governance is a governance that applies the principles of transparency, accountability, responsibility, independence and fairness (Bank Indonesia Regulation No. 8/4 / PBI / 2006 concerning Implementation Good Corporate Governance for Commercial Banks).

Principles of Good Corporate Governance

Every company must ensure that the principles of Good Corporate Governance are located in every aspect of the business and in all levels of the company. The principle of Good Corporate Governance, namely transparency, accountability, responsibility, independence, as well as fairness and equality is needed to achieve business 
sustainability (sustainability) of the company by taking into account stakeholders (Chartered Accountant Module, IAI, 2015: 80).

\section{Managerial ownership}

The size of the managerial shareholding in a company can indicate a congruence of interests between management and shareholders, but if the interests of managers and owners can be aligned, managers will not be motivated to manipulate information or manage earnings so that the quality of accounting information and earnings informativeness can increased (Pujiati and Arfan, 2013). It states that the greater the proportion of management ownership in a company will be able to unite the interests between managers and shareholders, so that the company's performance is getting better (Jensen, 1986) in Pujiningsih (2011).

\section{Profitability}

In the analysis of financial statements (Kasmir, 2012: 196), profitability ratios are ratios to assess the ability of companies to seek profits. According to Herdian (2015) Profitability is a performance indicator carried out by management in managing company wealth as indicated by the profits generated. This ratio also provides a measure of the effectiveness of a company's management. This is shown by the profits generated from sales and investment income. The point is this ratio shows the efficiency of the company (cashmere, 2012: 196).

\section{Solvency}

According to Van Horne 1997 in Yamadhitya (2014) the high leverage ratio shows that the company is not solvable, meaning that the total debt is greater than the total assets. Because leverage calculates how much funds are provided by creditors, if investors see the assets of a company that are high but the risk of leveraging is also high, will think twice about investing in the company because it is feared that high assets obtained from debt will increase investment risk if the company cannot pay off its obligations on time. Therefore, financial managers are required to manage solvency ratios properly so as to be able to balance high returns with the level of risk faced (Kasmir, 2012: 152).

\section{Company Size}

Manggau (2016) revealed that company size is one indicator used by investors in assessing assets and company performance. Company size is a scale where large or small companies can be classified according to various ways including total assets, log size, total sales, market value of shares, and others. The greater the total assets, sales, and market capitalization, the greater the size of a company. The greater the assets, the greater the capital invested, the more sales, the more money circulation and the greater market capitalization (Fadjriah Asyik, 2014). 


\section{Conceptual Framework}

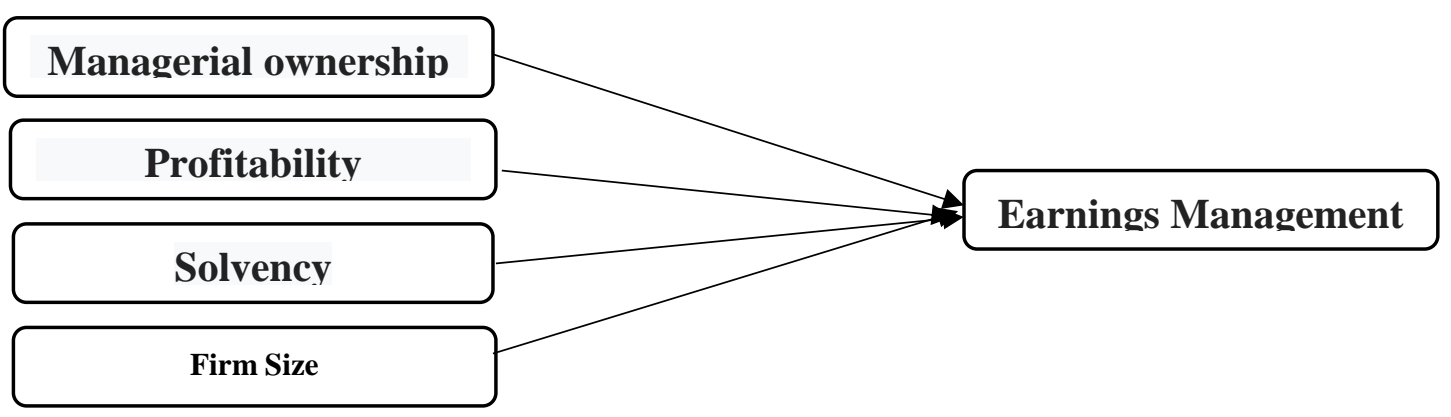

\section{Hypothesis Formulation \\ Managerial ownership}

Managerial ownership structure is the percentage of shares owned by directors and commissioners. Managerial ownership is one of the control mechanisms that can be carried out by shareholders to reduce earnings management. By giving managers the opportunity to engage in share ownership with the aim of aligning interests with shareholders, the manager's desire to maximize his own profits by managing earnings will be reduced. This is because the manager participates in the determination of accounting policies and procedures taken by the company, so that the higher managerial ownership, the management of earnings carried out will be increasingly reduced because the manager will share in taking every decision taken.

In research conducted by Fadjrih Asyik (2014) shows the results that managerial ownership has a positive influence on earnings management and can improve the quality of the financial reporting process, because when managers have a portion of ownership, they will act the same as general shareholders and ensure that financial statements have been presented fairly and reveals the real conditions of the company. The results of this study are consistent with the results of research conducted by Pujiati and Arfan (2013) that managerial ownership has a positive influence on earnings management.

\section{H1: Managerial Ownership Influences Profit Management}

\section{Profitability}

According to Herdian (2015) Profitability is a performance indicator carried out by management in managing company wealth as indicated by the profits generated. This ratio also provides a measure of the effectiveness of a company's management. This is shown by the profits generated from sales and investment income. The point is this ratio shows the efficiency of the company (cashmere, 2012: 196). In general, the value of a company's profitability can be used as an indicator to measure the performance of a company. The higher the profitability of a company, the company's performance and ability to generate profits is also high.

In research conducted by Selviani (2017) shows the results that profitability has a positive effect on earnings management. The positive meaning is that the higher the profitability, the more profit management increases, and conversely the lower the profitability, the lower the earnings management. The results of this study are 
supported by Frans (2015) which shows that profitability has a positive effect on earnings management.

\section{H2: Profitability Influences Profit Management,}

\section{Solvency}

According to Kasmir (2012: 151) the solvency ratio or leverage ratio is a ratio used to measure the extent to which a company's assets are financed with debt. This means how much debt burden borne by the company compared to its assets. Debt ratio is a debt ratio that is used to measure the ratio between total debt and total assets (Kasmir, 2012: 156).

Leverage has a relationship with earnings management practices, when a company has a high leverage ratio, the company tends to practice earnings management because the company is threatened that it cannot fulfill its obligations by paying its debts on time. So it can be concluded that, high leverage will also improve opportunistic behavior of management such as managing earnings to maintain its performance in the eyes of shareholders and the public and this is a result of lack of supervision and makes company management more difficult in making predictions of the way the company forward (Almadara , 2017).

In a study by Fatmasari (2016), the results show that leverage has a significant positive effect on earnings management. Likewise, the results of Agustia's (2013) study stated that leverage has a relationship with earnings management practices, investors will see the smallest corporate leverage ratio, because the smaller the company's leverage ratio or the smaller the capital financed by debt, the company has a small risk also, and vice versa. With these conditions can be used by managers to practice earnings management by manipulating their financial statements.

\section{H3: Solvency Influences Profit Management}

\section{Company Size}

Company size is one indicator used by investors in valuing assets and company performance. Company size is a scale where large or small companies can be classified according to various ways including total assets, log size, total sales, market value of shares, and others. The greater the total assets, sales, and market capitalization, the greater the size of a company. The greater the assets, the greater the capital invested, the more sales, the more money circulation and the greater the market capitalization (Nur Fadjriah, 2014).

Manggau (2016) explains that this is due to the greater size of the company, usually the information available to investors in making decisions regarding investment in the company's shares is more and more large companies are more considered by the public so they are more careful in reporting financial statements. In contrast to small companies that tend to practice earnings management, because small companies want to tend to pay attention to the condition of a company that always performs well so that potential investors invest their capital in the company (Restuwulan, 2013).

In research Fadjriah Asyik (2014) shows that company size has a significant effect on earnings management. This indicates that the size of the total sales of the company which shows the size of the company has an impact on earnings management by the company. This is due to the large tendency of smaller companies to take earnings management actions compared to smaller companies. The results of this study are 
supported by Vanian Yamaditya (2014) which shows that company size has a positive effect on earnings management.

\section{H4: Firm Size Affects Profit Management}

\section{RESEARCH METHODOLOGY}

Based on the type of data, this research uses a quantitative approach. Quantitative research is research in which data is quantitative data so that the data analysis uses quantitative analysis (inference) (Eksandy and Heriyanto, 2017: 6). In this study using secondary data in the form of financial statements. This type of research in terms of the level of explanation, categorized in the type of associative research. According to Eksandy and Heriyanto (2017: 8) associative research is research that seeks to find relationships between one variable and another. This study is to test the research hypothesis, namely the influence of independent variables consisting of managerial ownership, profitability, solvency, and company size on the dependent variable, earnings management.

Measurement of Variables and Operational Definitions

\begin{tabular}{|l|l|l|l|l|}
\hline \multicolumn{1}{|c|}{ Variable } & \multicolumn{1}{|c|}{$\begin{array}{c}\text { Kinds of } \\
\text { Variable }\end{array}$} & \multicolumn{1}{|c|}{ Indicator } & Kinds of Data & Scale \\
\hline $\begin{array}{l}\text { Earnings } \\
\text { management }\end{array}$ & Dependent & $\begin{array}{l}\text { Discretionary Revenue } \\
\text { (Model Stubben) }\end{array}$ & Secondary & Ratio \\
\hline $\begin{array}{l}\text { Managerial } \\
\text { Ownership }\end{array}$ & Independent & $\begin{array}{l}\text { Managerial Ownership } \\
\text { of stock }\end{array}$ & Secondary & Ratio \\
\hline Profitability & Independent & $\begin{array}{l}\text { Return On Equity } \\
\text { (ROE) Secondary }\end{array}$ & Ratio \\
\hline Solvency & Independent & $\begin{array}{l}\text { Debt To Asset Ratio } \\
\text { (DAR) }\end{array}$ & Secondary & Ratio \\
\hline Firm size & Independent & Logaritma Natural & Secondary & Ratio \\
\hline
\end{tabular}

RESEARCH RESULTS AND DISCUSSION

Descriptive Statistical Analysis

\begin{tabular}{|c|c|c|c|c|c|}
\hline & ML & $\mathbf{K M}$ & ROE & DAR & SIZE \\
\hline Mean & 1.749410 & 2.670180 & 0.151535 & 0.347518 & 29.05500 \\
\hline Median & 1.682350 & 0.320550 & 0.142950 & 0.345850 & 29.12500 \\
\hline Maximum & 19.41420 & 24.28040 & 0.320800 & 0.659000 & 30.78000 \\
\hline Minimum & -39.30560 & 0.015800 & 0.018000 & 0.068700 & 26.63000 \\
\hline Std. Dev. & 8.648818 & 6.342173 & 0.082045 & 0.167067 & 1.157725 \\
\hline Skewness & -2.589349 & 3.040867 & 0.524661 & 0.012517 & -0.450532 \\
\hline Kurtosis & 14.36777 & 10.65171 & 2.528669 & 2.101812 & 2.622226 \\
\hline Observations & 40 & 40 & 40 & 40 & 40 \\
\hline
\end{tabular}

Based on the table above it can be explained that the amount of data used in this study was 40 data for all dependent and independent variables used in the study. The largest mean value is the SIZE variable that is equal to 29,05500, while the ROE variable has the 


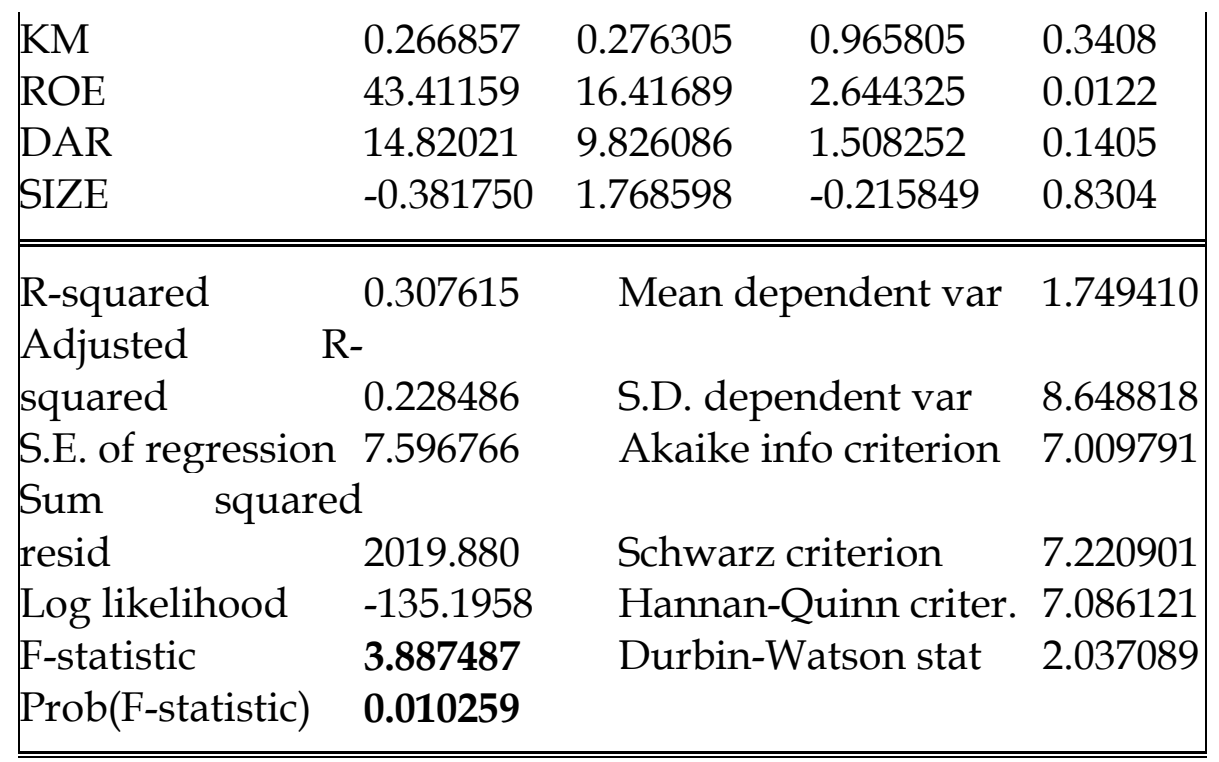

Based on the table above shows that the results of the $t$ test are as follows:

1. KM t-statistic value is 0.965805 , while $t$-table level $a=5 \%$, $d f(n-k)=35$ is obtained $\mathrm{t}$ table value of 2.030108. Therefore t-statistic KM $0.965805<\mathrm{t}$-Table 2.030108 and Prob value. 0.3408> 0.05. Then Ho is accepted, which means managerial ownership variables in this study have no influence on earnings management.

2. ROE t-statistic value is 2.644325 , while $\mathrm{t}$-table level $\mathrm{a}=5 \%$, $\mathrm{df}(\mathrm{n}-\mathrm{k})=35$ is obtained $\mathrm{t}$ table value of 2.030108 . Therefore $\mathrm{t}$-statistic ROE 2.644325> t-Table 2.030108 and Prob value. $0.0122<0.05$. Then Ha is accepted, which means the profitability variable in this study has a positive influence on earnings management.

3. D-statistic value of DAR is 1.508252, while t-table level $a=5 \%$, df $(n-k)=35$ obtained $\mathrm{t}$-table value of 2.030108. Thus the t-statistic DAR $1.508252<\mathrm{t}$ Table 2.030108 and the Prob value. 0.1405> 0.05. So Ho is accepted, which means the solvency variable in this study has no effect on earnings management.

4. SIZE $\mathrm{t}$-statistic value of -0.215849 , while $\mathrm{t}$-table level $\mathrm{a}=5 \%$, df $(\mathrm{n}-\mathrm{k})=35$ obtained $\mathrm{t}$-table value of 2.030108 . Thus $\mathrm{t}$-statistic SIZE $-0.215849<\mathrm{t}$ Table 2.030108 and Prob value. 0.8304> 0.05. Then Ho is accepted, which means the company size variable in this study has no influence on earnings management.

\section{Panel Data Regression Equation}

Based on the results of the panel data regression model analysis with the EViews 9.0 program, the data obtained from the panel data regression model are as follows: 


\section{Interpretation of Results}

\section{Effect of Managerial Ownership on Earnings Management}

Based on table above the managerial ownership variable (KM) has a t-statistic value of 0.965805 and a significant value of 0.3408 which means it is greater than 0.05 . Thus that managerial ownership variable (KM) has no effect on earnings management. This means that this research has not been able to prove $\mathrm{H} 1$ which states that managerial ownership has a significant effect on earnings management.

Managers who own company shares tend to adopt policies to manage earnings from the perspective of investors' desires, for example by increasing reported profits so that many investors are interested in investing and can raise the price of company shares. The failure of the management which is also the owner of the company's capital in improving the quality and financial reporting process is caused by the percentage of managers who have relatively small shares when compared to the overall capital owned by general investors. This means that the number of shares owned by the company's management cannot affect the size of the earnings management carried out by the company.

The results of this study are in line with research conducted by Agustia (2013) which states managerial ownership has no effect on earnings management. This is because the percentage of managers who own shares is relatively very small when compared to the overall capital owned by general investors. The results of this study are not in line with research conducted by Fadjrih Asyik (2014) showing that managerial ownership has a positive effect on earnings management and can improve the quality of the financial reporting process, because when managers have a portion of ownership, they will act the same as shareholders and ensure that reports The financial statements have been presented fairly and revealed the real conditions of the company.

\section{Effect of Profitability on Earnings Management}

Based on table above profitability variable (ROE) has a t-statistic value of 2.644325 and a significant value of 0.0122, which means it is smaller than 0.05. Thus that the profitability variable (ROE) has a significant positive effect on earnings management. So H2 is accepted which states that Profitability has a Significant Effect on Earnings Management.

The meaning of the positive sign is the higher the profitability, the more profit management increases. This happens to companies in Indonesia, especially property and real estate sub-sector companies that have large profits or are experiencing an increase in profits, which is more possible to practice earnings management than companies that have small profits or are experiencing a decline in profit. Companies that have high profits tend to report their profits are smaller than actual profits, because companies that have high profits will tend to be paid more attention or highlighted by the government and society than companies that have small profits. Profit generated by the company during the year can be an indicator of earnings management. This is because earnings management patterns that are most widely used in companies are income maximizing or the increase in profits as the results in this study that most of the sample sub-sector property and real estate do a pattern of increasing profits.

The results of this study are in line with research conducted by Selviani (2017) showing the results that profitability has a positive effect on earnings management. The higher the profitability, the more profit management increases. Conversely the lower the 
profitability, the lower the earnings management. But this research is not in line with research conducted by Fatmasari (2016) that profitability has no effect on earnings management. This means that earnings management is not influenced by high or low profitability.

\section{Effect of Solvency on Profit Management}

Based on table above the solvency variable (DAR) has a t-statistic value of 1.508252 and a significant value of 0.1405 which means it is greater than 0.05 . Thus that the solvency variable (DAR) has no effect on earnings management. This means that this research has not been able to prove H3 which states that Solvency has a Significant Effect on Earnings Management.

Leverage ratios are used to measure a company's ability to meet its long-term obligations. The greater the debt owned by the company, the greater the value of the leverage of a company. Companies with a high degree of leverage will face a high risk of default, which is a company that is threatened to be unable to meet its obligations. Earnings management actions cannot be used as a mechanism to avoid these defaults. In the sense that the company is able to pay the debt used to finance the company's assets, then the manager is not interested or not motivated to practice earnings management. This is because the company does not need actions that will help the company in certain situations.

The results of this study are in line with research conducted by Selviani (2017) showing that solvency has no effect on earnings management. This shows that the high and low leverage will not affect the company to conduct earnings management. The results of this study are not in line with research conducted by Agustia (2013) that solvency has a significant effect on earnings management. These results indicate that companies that have high leverage ratios, means the proportion of debt is higher than the proportion of its assets will tend to manipulate in the form of earnings management.

\section{Effect of Company Size on Profit Management}

Based on table above the company size variable (SIZE) has a t-statistic value of 0.215849 and a significant value of 0.8304 which means it is greater than 0.05 . Thus that the company size variable (SIZE) has no effect on earnings management. This means that this research has not been able to prove $\mathrm{H} 4$ which states that company size has a significant effect on earnings management.

The size of the company is a value that indicates the size of the company. There are two views about the shape of the relationship between company size and earnings management. The first view states that company size has a positive relationship with earnings management, because large companies have more complex operational activities than small companies, making it more possible to do earnings management. The second view states that company size has a negative relationship with earnings management. Large companies have a tendency to do earnings management actions that are smaller than smaller companies, while smaller companies have a tendency to do earnings management actions that are larger. This is because large companies are seen as more critical by shareholders and outsiders so that large companies get stronger pressure to present credible financial reporting (Restuwulan, 2013). 
The results of this study are in line with research conducted by Selviani (2017) showing the results that company size has no effect on earnings management. Companies that have a large scale, the possibility of earnings management is less likely, compared to companies that have a small scale and large companies are more critically viewed by shareholders and outsiders. This research is not in line with research conducted by Fadjrih Asyik (2014) which states that company size has a positive effect on earnings management. This indicates that the size of a company will have an impact on earnings management by the company. This makes the policies of large companies will have a greater impact on the public interest compared to small companies. Large companies are more considered by the public so they are more careful in conducting financial reporting that impacts on these companies must report their conditions more accurately.

\section{CONCLUSION}

Based on the results of the analysis and discussion described in the previous chapter, the conclusions of this study are as follows:

1. Managerial Ownership has no effect on Earnings Management with a significant value of 0.3408 greater than 0.05 . This means that there is no influence of the relationship between managerial ownership on earnings management. The failure of the management which is also the owner of the company's capital in improving the quality and financial reporting process is caused by the percentage of managers who have relatively small shares when compared to the overall capital owned by general investors. This indicates that the number of shares owned by the company's management cannot influence the size of the earnings management carried out by the company.

2. Profitability has a positive effect on earnings management with a significant value of 0.0122 less than 0.05 . This means that there is an influence of the relationship between profitability on earnings management. this indicates that the higher the profitability the more profit management increases. Conversely the lower the profitability, the lower the earnings management. This is because earnings management patterns that are most widely used in companies are income maximizing or the increase in profits as the results in this study that most of the sample sub-sector property and real estate do a pattern of increasing profits.

3. Solvency does not affect Profit Management with a significant value of 0.1405 greater than 0.05. This means that there is no influence of the relationship between solvency to earnings management. This shows that the high and low leverage will not affect the company to conduct earnings management. In the sense that the company is able to pay the debt used to finance the company's assets, then the manager is not interested or not motivated to practice earnings management.

4. Company size has no effect on earnings management with a significant value of 0.8304 greater than 0.05 . This means that there is no influence of the relationship between company size on earnings management. Companies that have a large scale, the possibility of earnings management is less likely, compared to companies that have a small scale and large companies are more critically viewed by shareholders and outsiders. 


\section{REFERENCES}

Agustia, Dian. 2013. Jurnal Akuntansi dan Keuangan Vol. 15, No. 1, Mei 2013

Almadara, Hafidza Ulfa, 2017. Pengaruh Leverage Terhadap Manajemen Laba

Dengan Corporate Governance Sebagai Variabel Moderasi. Universitas Negeri Yogyakarta. 2017.

Dermawan, Sjahrial, 2010. Manajemen Keuangan, Edisi Keempat, Mitra Wacana Media, Jakarta.

Dewi, Mila Mega dan Sri Sulasmiyati. 2018. Pengaruh Struktur Kepemilikan, Ukuran Perusahaan Dan Profitabilitas Terhadap Leverage, Jurnal Administrasi Bisnis (JAB) | Vol. 55 No. 1 Februari 2018.

Eksandy, Arry dan Freddy Heriyanto. 2017. Metode Penelitian Akuntansi dan Keuangan.

Fahmi, Irham. 2013. Analisis Laporan Keuangan. Bandung: Alfabeta.

Fatmasari, Sofia. 2016. Pengaruh Profitabilitas dan Leverage Terhadap Manajemen

Laba. Sekolah Tinggi Ilmu Ekonomi Perbanas. Surabaya. 2016

Forum For Corporate Governance in Indonesia (FCGI), 2001. Seri Tata Kelola

Perusahaan (Corporate Governance): Corporate Governance (Tata Kelola

Perusahaan), Jilid 1, Edisi 3, Jakarta.

Frans, Dody. 2015. Pengaruh Profitabilitas, CG, Ukuran Perusahaan, dan Leverage terhadap Manajelem Laba, Universitas Islam Negri Syarif Hidayatullah, Jakarta.

Herdian, Cristopher Henry. 2015. Pengaruh Good Corporate Governance, Profitabilitas, Free Cash Flow Dan Leverage Terhadap Manajemen Laba. Universitas Diponegoro, Semarang. 2015.

Ikatan Akuntan Indonesia (IAI). 2015. Modul Chartered Accountant: Etika Profesi dan Tata Kelola Korporat. Jakarta, Indonesia: Penulis.

Ikatan Akuntansi Indonesia. 2015. PSAk No. 50 (Revisi 2015) : Penyajian Instrumen

Keuangan . Jakarta: IAI

Istianingsih. 2016. Deteksi Manajemen Laba Melalui Discretionary Revenue dan Aktifitas Rill: Implikasi Penerapan Good Corporate Governance. Jurnal Riset Akuntansi dan Keuagan, 4 (3), 2016, 1125-1142

Kasmir. 2012. .Analisis Laporan Keuangan, PT Raja Grafindo Persada, Jakarta.

Kieso E. Donald, Weygandt J Jerry, dan Warfild. D.Terry. (2007). Intermediate Accounting. Edisi Keduabelas. Jilid 1. Penerbit Erlangga, Jakarta.

KNKG (Komite Nasional Kebijakan Governance). (2006). Pedoman Umum Good Corporate Governance Indonesia. Artikel. Diakses tanggal 19 April 2018, dari

www.governance-indonesia.com.

Larasati, Indri. 2017. Analisis Faktor - Faktor Yang Mempengaruhi Pertumbuhan Ekonomi. Universitas Islam Indonesia. Fakultas Ekonomi. Yogyakarta.

Manggau, Anatasia Wenny. 2016. Pengaruh Asimetri Informasi Dan Ukuran Perusahaan Terhadap Manajemen Laba Pada Perusahaan Pertambangan Yang

Terdapat Di Bursa Efek Indonesia. Jurnal Ekonomi dan keuangan Volume 13, (2), 2016 Pujiati, Evi Juniali dan Muhammad Arfan, 2013. Struktur Kepemilikan Dan Kompensasi Bonus Serta Pengaruhnya Terhadap Manajemen Laba, Jurnal Telaah \& Riset Akuntansi, Vol. 6 No. 2 Juli 2013. 
Pujiningsih, Andiany Indra. 2011. "Pengaruh Struktur Kepemilikan, Ukuran Perusahaan, Praktik Corporate Governance dan Kompensasi Bonus Terhadap Manajemen Laba". Universitas Diponegoro, Semarang.

Rahmadeni dan Eka Yonesta. 2016. Analisis Regresi Data Panel Pada Pemodelan Produksi Panen Kelapa Sawit Di Kebun Sawit Plasma Kampung Buatan Baru. Jurnal Sains Matematika dan Statistika, Vol. 2, No. I, Januari 2016.

Restuwulan. 2013."Pengaruh Asimetri Informasi dan Ukuran perusahaan Terhadap Manajemen Laba Pada Perusahaan Sektor Industri Food and Beverages yang terdapat di BEI". Universitas Widyatama.

Selviani, Alesia Heni. 2017. Pengeruh Profitabilitas, Leverage dan Ukuran Perusahaan Terhadap Manajemen Laba. Universitas Sanata Dharma, Yogyakarta. 2017. Sugiyono, 2013. Metode Penelitian Kuantitatif, Kualitatif R\&D. Bandung: Alfabet.

Sulistyanto, H. Sri. 2014. Manajemen Laba, Teori dan Model Empiris. Jakarta: Grasindo.

Sutarmin, Achmad. 2017. Mekanisme Good Corporate Governance Terhadap Praktik Manajemen Laba. JMM Vol. 13 No. 2 Oktober 2017

Sutikno, Frendy; Wahidahwati, dan Nur Fadjrih Asyik, (2014). Pengaruh Corporate Governance dan Ukuran Perusahaan Terhadap Manajemen Laba. Jurnal Ilmu dan Riset Akuntansi. Vol. 3, No. 10, 2014.

Suyono, Eko. 2017. Berbagai Model Pengukuran Earnings Management: Mana Yang Paling Akurat. Purwokerto, 20 September 2017 